\title{
The Uluguru Mountains of eastern Tanzania: the effect of forest loss on biodiversity
}

\author{
Neil Burgess, Nike Doggart and Jon C. Lovett
}

\begin{abstract}
The Uluguru Mountains in eastern Tanzania contain at least 16 endemic vertebrate and 135 endemic plant taxa, with hundreds of more taxa shared only with forests in eastern Tanzania and Kenya. This degree of endemism is exceptional in tropical Africa, and the Uluguru Mountains are one of the 10 most important tropical forest sites for conservation on the continent. Surveys carried out during 1999-2001 updated information on the status of forests and biodiversity across the Uluguru Mountains. Forest area has declined from c. $300 \mathrm{~km}^{2}$ in 1955 to $230 \mathrm{~km}^{2}$ in 2001. Forest loss has been greatest over altitudes of $600-1,600 \mathrm{~m}$, and concentrated in submontane forest. During the recent surveys most of the endemic and near-endemic vertebrate species known from the Uluguru Mountains were re-recorded, but
\end{abstract}

three endemic snake species and two near-endemic bird species were not found. These species were previously known from the elevations where deforestation has been greatest. More than 50 plant species are also known only from the altitude range that has been heavily deforested. The primary cause of forest loss has been clearance for new farmland. The forest that does remain is largely confined to Catchment Forest Reserves managed for water by the Tanzanian Government. Without these reserves the loss of forest, and hence the loss of biodiversity, in the Uluguru Mountains would most likely have been much greater.

Keywords Biodiversity, East Africa, endemic species, extinction risk, forest loss, Tanzania, Uluguru Mountains.

\section{Introduction}

The Uluguru Mountains of eastern Tanzania form one of the component blocks of the Eastern Arc Mountains of Kenya and Tanzania (Fig. 1). This mountain range, composed of ancient Precambrian igneous and metamorphic rocks, stretches from the Taita Hills in southern Kenya to the Udzungwa Mountains in south-central Tanzania, and is under the climatic influence of the Indian Ocean (Lovett, 1988, 1990). The Eastern Arc has long been known as a centre of both floral (Polhill, 1968) and faunal (Allen \& Loveridge, 1927; Loveridge, 1942; Moreau, 1966) diversity and endemism.

The unique nature of the Eastern Arc Mountains was recognized in the Tanzania Forest Action Plan (BenstedSmith \& Msangi, 1989), a planning process supported by the Tanzanian government. The Eastern Arc Mountains

Neil Burgess ${ }^{1}$ (Corresponding author) and Nike Doggart Wildlife Conservation Society of Tanzania, Uluguru Mountains Biodiversity Conservation Project, P.O. Box 312, Morogoro, Tanzania.

Jon Lovett Environment Department, University of York, Heslington, York, Y010 5DD, UK

${ }^{1}$ Present address: WWF-US, 1250 24th Street, Washington D.C., 20037-1193, USA. E-mail: neil.burgess@wwfus.org

Received 27 March 2001. Revision requested 21 August 2001. Accepted 28 January 2002. have also been recognized by BirdLife International (ICBP, 1992; Stattersfield et al., 1998), Conservation International (Mittermeier et al., 1998, 1999; Myers et al., 2000) and the World Wildlife Fund (Olson \& Dinerstein, 1998) as an area of global importance for the conservation of biodiversity. Moreover, the importance of the Eastern Arc and adjacent lowland coastal forests were highlighted in the Country Study on Biodiversity (Government of Tanzania, 1998), and in the Tanzania Forest Programme (Government of Tanzania, 2001).

The Uluguru Mountains range from c. $150 \mathrm{~m}$ altitude on their south-eastern margin to over $2,630 \mathrm{~m}$ at their highest point. In total they cover $c .1,500 \mathrm{~km}^{2}$ of highlands, mainly in a ridge running almost north-south, but with a few outlying hills. The mountains are steep, with extensive cliffs and rock outcrops, and formerly the natural vegetation, particularly of the eastern face, was moist forest. At lower altitudes and on the western slopes below c. 1,000 $\mathrm{m}$ this forest would formerly have graded into savannah woodland, but farmland now largely obscures these transitions. At high elevations in the southern Uluguru mountains the forest gives way to grassland in flatter areas, and to elfin forest on the wetter peaks above $2,000 \mathrm{~m}$. The lowest altitude of the forest now varies along the range. Around Uluguru South Forest Reserve (Fig. 2) the lower border is $>1,500 \mathrm{~m}$ on the eastern face, and at c. $2,000 \mathrm{~m}$ on the western face. It is only in Uluguru North Forest Reserve, 
Fig. 1 The Eastern Arc Mountains of Kenya and Tanzania. The small rectangle indicates the position of the Uluguru Mountains (see Fig. 2).

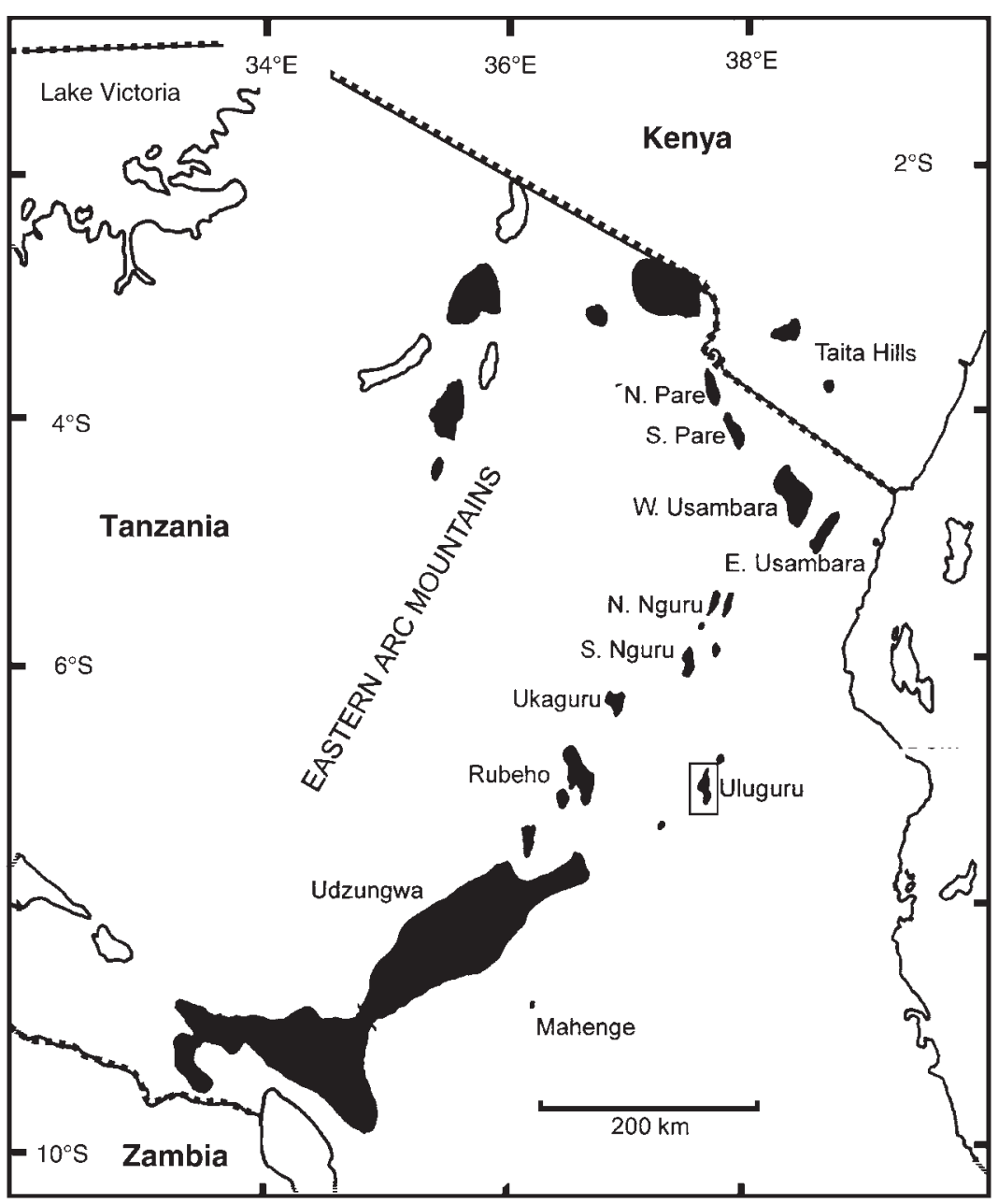

especially in the northern part of the Reserve and the adjacent forests, that significant areas of submontane forests still exist down to $c .1,000 \mathrm{~m}$.

The Uluguru Mountains receive one of the highest rainfalls in Tanzania, and form the most important water catchment forest in the country, supplying the Ruvu River. This is the principal water supply to Dar es Salaam, where 3-4 million people and most of the industry of Tanzania is based (Jackson, 1970; Temple, 1972a, b; Bensted-Smith \& Msangi, 1989). The eastern face of these mountains receives $>3,000 \mathrm{~mm}$ of rain per year, with at least $100 \mathrm{~mm}$ of rain in every month, and the forests are thus per-humid, which is unusual in Africa.

In an assessment of the water catchment and biological values of Tanzanian Catchment Forest Reserves, which are administered by central government, the reserves on the Uluguru Mountains were ranked at the highest level of importance (Lovett \& Pócs, 1993; Lovett, 1998; Pócs, 1998). These mountains have recently been assessed as the third most important mountain block for the conservation of endemic fauna in the Eastern
Arc Mountains (Burgess et al., 1998b). Plant and animal species endemic to the Uluguru Mountains occur throughout the altitudinal range of the mountains and, although found in both forest and non-forest habitats, are concentrated in the natural forests.

The Uluguru Mountains Biodiversity Conservation Project (UMBCP) is a collaboration between the Wildlife Conservation Society of Tanzania (which represents BirdLife International in Tanzania), the Danish Ornithological Society (BirdLife Denmark), the Morogoro Regional Catchment Forest Project Office, the Morogoro Natural Resources Office and the University of Sokoine in Morogoro. Funding for the project comes from the Danish Development Agency, DANIDA. One of the aims of the project is to collect and distribute data on the status and condition of the Uluguru forests and their biodiversity. The project has pursued this aim since 1999, but it builds upon two decades of field work and data compilation (Pócs, 1976a, b; Rodgers et al., 1983; Lovett \& Pócs, 1993, Lovett \& Wasser, 1993; Svendsen \& Hansen, 1995; Burgess et al., 1998a, b, c; Burgess \& Clarke, 2000). 


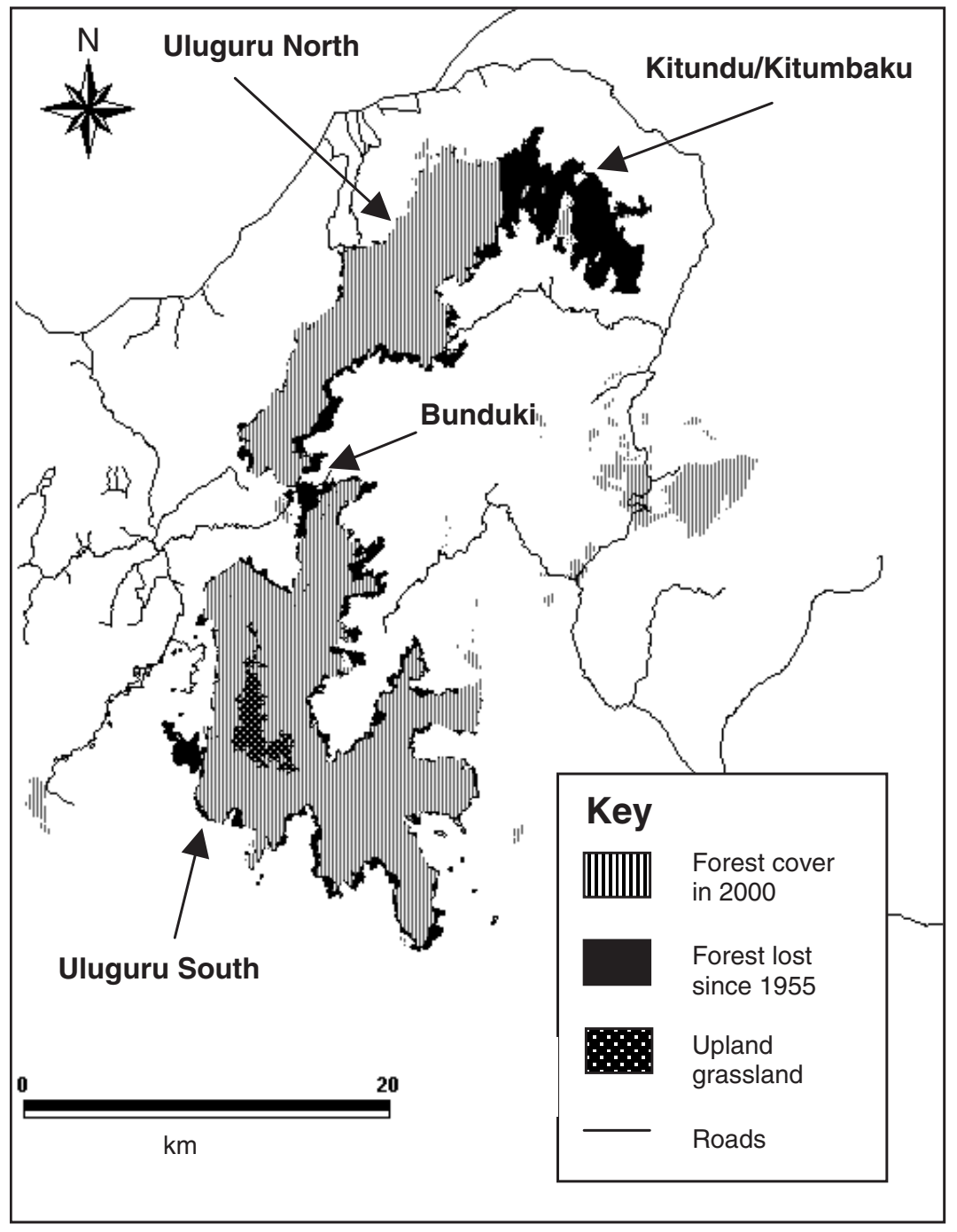

Fig. 2 The distribution of forest cover in the Uluguru Mountains in 1955 and 2000, indicating the main areas of forest loss.
In this paper we use the new data collected by the UMBCP to summarize and assess the changes that have occurred in forest cover since 1955, and update information on the total number of plant and vertebrate animal species endemic to the Uluguru Mountains and on their altitudinal ranges. These results enable us to assess whether any endemic species have been lost from the Uluguru Mountains, and whether reasons can be determined for any such losses.

\section{Methods}

\section{Forest cover and status}

We determined forest cover from aerial photographs taken in 1955 and 1977, digitised with the geographical information system ArcInfo (ESRI, 2000). Present-day forest cover was assessed from field surveys of the borders of all forest reserves on the Uluguru Mountains from late 1999 through to the middle of 2001. Patches of forest remaining on farmed lands outside the Forest Reserves were also mapped during 2000 (Hymas, 2000). A topographical model of the Uluguru Mountains was built with ArcInfo and, in combination with the digitized photographs, was used to determine forest cover in $100 \mathrm{~m}$ bands of altitude in 1955 and 1977. The status of the land of the Uluguru Mountains was assessed from the records of the Tanzanian government. All Forest Reserves were mapped with ArcInfo, and details of their area, date gazetted, management history, and current land-use were summarized from literature and field visits (Hymas, 2000; Doggart et al., 2001). If field surveys located areas of forest outside government Forest Reserves then the ownership of these areas was also established and the areas were described. 


\section{Biological data}

Historical data on the endemic vertebrate animal and plant species of the Uluguru Mountains were obtained from the literature. Vertebrate animal data comes mainly from expeditions undertaken in the early 1900s (Allen \& Loveridge, 1927; Barbour \& Loveridge, 1928; Loveridge, 1942), and from scientific investigations in the late 1970s and early 1980s (Rodgers et al., 1983; Stuart \& Jensen, 1985). Data include an assessment of the altitudinal range of each species. Data collected from all forest reserves by the UMBCP during 1999-2000 was used to confirm whether the endemic vertebrate species still occur in these mountains (Doggart et al., 2001). These data are held at the Tanzanian Biodiversity Database at the University of Dar es Salaam and the biodiversity database of the UMBCP in Morogoro. Summary reports are available at http://www.africanconservation.com/ uluguru. In addition to these data, recent records of some endemic species were taken from Svendsen \& Hansen (1995), Stanley et al. (1998), and from the Tanzania Biodiversity Database (K. Howell, in lit.).

A provisional list of the endemic plants of the Uluguru Mountains was derived from the List of East African Plants (LEAP, 1995), augmented by visits to Lushoto,
Arusha and Dar es Salaam herbaria in Tanzania (Temu \& Nsolomo, 2000). This provisional list was revised by J.L. using both published and completed, but unpublished, parts of the Flora of Tropical East Africa, together with other taxonomic literature. A total of 206 angiosperm and pteridophyte families were checked, of which 14 were unpublished at the time of checking, and only parts 1 and 2 of Compositae were available. Family accounts not checked that have known Uluguru endemic species are Acanthaceae and Gesneriaceae.

\section{Analytical units}

In the analysis of faunal endemism we classified the forests of the Uluguru Mountains by elevation into lowland $(<800 \mathrm{~m})$, submontane $(800-1,400 \mathrm{~m})$, montane $(1,400-1,800 \mathrm{~m})$ and upper montane $(>1,800 \mathrm{~m})$ zones (Lovett, 1993a). If an endemic species has an altitudinal range of $500-2,000 \mathrm{~m}$ it is assessed in all four altitudinal bands; if its altitudinal range is less, then it falls in fewer of these bands. The habitat of endemic plant species was categorized as forest and non-forest, and the altitudinal range of taxa was categorized into $200 \mathrm{~m}$ bands of altitude.
Fig. 3 Area of forest on the Uluguru Mountains in bands of $100 \mathrm{~m}$ altitude, in 1955 (grey bars) and 1977 (white bars).

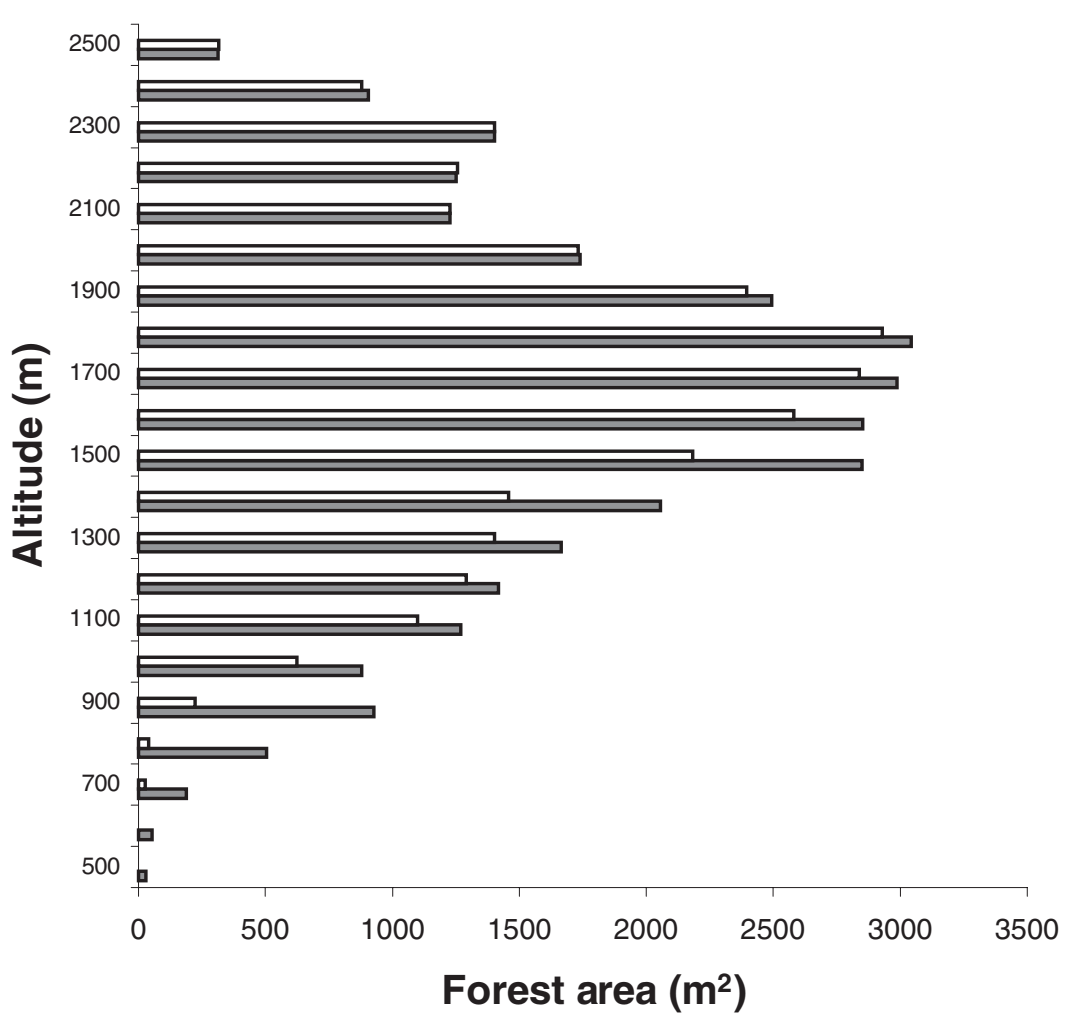




\section{Results}

\section{Forest cover}

There has been extensive loss of forest on the Uluguru Mountains (Figs. 2 \& 3). Using climatic data and the presence of forest patches to define historical forest limits we estimate the potential natural closed forest cover in the Uluguru Mountains to be $c .500 \mathrm{~km}^{2}$. In 1955 the forest cover was $300 \mathrm{~km}^{2}, 200 \mathrm{~km}^{2}$ less than the estimated potential cover. Between 1955 and 1977 the area of forest declined by a further $40 \mathrm{~km}^{2}$ to $260 \mathrm{~km}^{2}$. Field assessments of the current geographical extent of the remaining forest indicate that c. $230 \mathrm{~km}^{2}$ remains. i.e. $<40 \%$ of the potential forest area. The rate of forest loss was $1.7 \%$ per annum over $1955-1977$, and $0.6 \%$ per annum over 1977-2000. Loss of forest over 1955-1977 occurred almost entirely outside the Forest Reserves, over altitudes of 500-1,600 m (Fig. 3), and forest loss since 1977 has also occurred at the lower altitudes. Today some middle altitudes contain almost no forest at all.

Most of the loss has been caused by change in land use from forest to farms, and the apparent recent slowing of forest loss may be due to the fact that, as forest is lost outside the Uluguru Forest Reserves there is less forest available for conversion into farmland. Farmers grow maize, cassava, bananas and oranges at lower elevations, and at the cooler temperatures of higher altitudes they grow crops such as cabbage, potatoes and peas. Over large areas of the Uluguru Mountains fallow fields become infested by bracken Pteridium aquilinum, and are used for farming on rotations of several years.

Evergreen forest on the Uluguru Mountains is now almost entirely confined to Catchment Forest Reserves, managed centrally by the Tanzanian government. Our assessment of the vegetation in the 22 Forest Reserves (Table 1) shows that 15 have predominantly natural evergreen forest cover and seven are either woodlands, plantations or are deforested. Forest formerly existed on village lands, but these have largely been cleared. For example, in the past $10-15$ years $c .20 \mathrm{~km}^{2}$ of forest has been lost on the Kitundu/Kitumbaku Hills outside the Uluguru North Forest Reserve in the north-east (Fig. 2). This large area of forest was formerly under the authority of the traditional Chief who maintained the forest for the ancestors of the Luguru tribe, but political changes since 1964 have meant that his authority has been gradually eroded. The loss of chiefly power, and associated forest clearance, has accelerated in recent decades (Hymas, 1999). Other patches of forest remain in the farmlands around the Uluguru Mountains, but these are small and are still being cleared for smallholdings, except where they have traditional religious significance or are found on rocky outcrops. Farmlands do not offer suitable habitat for the Uluguru endemic vertebrates, but some endemic plant species may persist along streams or on rocky outcrops.

\section{Biodiversity}

Of the endemic vertebrate species in the Uluguru Mountains (Table 2) the highest diversity is in the montane forest band (Fig. 4). Recent surveys of birds (Svendsen \& Hansen, 1995; Doggart et al., 2001), mammals (Stanley et al., 1998; Perkin, 2000; Doggart et al., 2001), reptiles (Doggart et al., 2001) and amphibians (Channing, 2000; Doggart et al., 2001) have recorded 11 of the 16 known Uluguru endemic animal species (Table 2). Of the nearendemic species shared only with other Eastern Arc Mountains we have managed to locate all of the mammal, reptile and amphibian species (Doggart et al., 2001). The recent surveys also discovered four rare species (the bat Myonycteris relicta, the rodent Beamys hindei, the chameleon Chamaeleo deremensis and the snake Atheris ceratophorus), which were previously only known from other montane Eastern Arc or lowland coastal forests (Doggart et al., 2001). The discovery of species not previously recorded on the Uluguru Mountains shows that the area is yet to be adequately surveyed.

However, recent surveys have failed to rediscover species that occurred on the Uluguru Mountains in the past, including several endemic species. Recent surveys of birds (Stuart \& Jensen, 1985; Svendsen \& Hansen, 1995; Doggart et al., 2001) have failed to locate the Endangered Tanzanian Mountain Weaver Ploceus nicolli, which inhabits mature submontane and montane forest, and the Vulnerable Banded Green Sunbird Anthreptes rubritorques known from submontane forest. Four endemic species of vertebrate have also not been recorded in the last 10 years: the sub-species of golden mole Chrysochloris

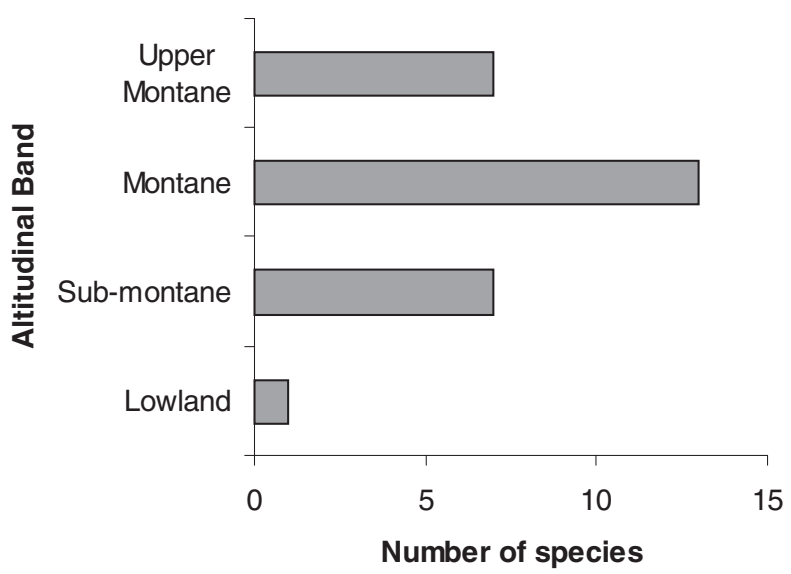

Fig. 4 Number of endemic vertebrate taxa in the major altitudinal zones of forest on the Uluguru Mountains. 
Table 1 Forest Reserves of the Uluguru Mountains, with notes on their current status (from Lovett and Pócs, 1993, updated from field surveys in 1999 and 2000).

\begin{tabular}{|c|c|c|c|c|}
\hline $\begin{array}{l}\text { Name of } \\
\text { Forest Reserve }\end{array}$ & Ownership* & $\begin{array}{l}\text { Govt. Declaration } \\
\text { Number }\end{array}$ & $\begin{array}{l}\text { Area } \\
\text { (ha) }\end{array}$ & Brief description of the vegetation and status of the reserve \\
\hline Bunduki I-iii & CFR & Cap. 1321950 & 111 & $\begin{array}{l}\text { Plantation and natural forest. Plantation is being logged on licence. Fuel and } \\
\text { pole gathering. }\end{array}$ \\
\hline Bunduki iv & CFR & Cap. 1321950 & 6 & $\begin{array}{l}\text { Plantation and natural forest. Plantation is being logged on licence. Fuel and } \\
\text { pole gathering. }\end{array}$ \\
\hline Bunduki v & CFR & Cap. 1321950 & 4 & $\begin{array}{l}\text { Plantation and natural forest. Plantation is being logged on licence. Fuel and } \\
\text { pole gathering. }\end{array}$ \\
\hline Bunduki vi & CFR & Cap. 1321950 & 3 & $\begin{array}{l}\text { Plantation and natural forest. Plantation is being logged on licence. Fuel and } \\
\text { pole gathering. }\end{array}$ \\
\hline Chamanyani & CFR & Cap. 1321950 & 796 & $\begin{array}{l}\text { Mainly woodland with a few riverine forest strips. A little logging. Fuel and } \\
\text { pole gathering. }\end{array}$ \\
\hline Kasanga & CFR & 1907 & 70 & $\begin{array}{l}\text { Mainly a plantation, but with some natural forest regrowth. Being logged } \\
\text { and farmed. Fuel and pole gathering. }\end{array}$ \\
\hline Kimboza & CFR & 1907 & 386 & $\begin{array}{l}\text { Some natural forest and some plantation. Joint Forest Management } \\
\text { experiments here. Fuel and pole gathering. }\end{array}$ \\
\hline Mindu & CFR & CFR & 2285 & $\begin{array}{l}\text { Outlying hill west of Ulugurus. Mainly woodland with a little forest on the } \\
\text { top. Some damage from logging. Fuel and pole gathering. }\end{array}$ \\
\hline Mkungwe & CFR & 1954 & 1967 & $\begin{array}{l}\text { Outlying hill east of Ulugurus. Lowland to submontane forest in good } \\
\text { condition. Some new pit sawing. Fuel and pole gathering. }\end{array}$ \\
\hline Mvuha & CFR & Cap. 1321950 & 852 & $\begin{array}{l}\text { Mainly woodland with a few riverine forest strips. A little logging. Fuel and } \\
\text { pole gathering. }\end{array}$ \\
\hline Nyandiduma & CFR & Cap. 1321950 & 48 & A plantation of Eucalyptus that is being cut. Fuel and pole gathering. \\
\hline Nyandira & CFR & German colonial & 195 & A plantation of Eucalyptus that is being cut. Fuel and pole gathering. \\
\hline Palangwe East & CFR & 1963 & 768.5 & $\begin{array}{l}\text { Woodland that burns ever year. Not valuable for water catchment. Fuel } \\
\text { wood gathering. }\end{array}$ \\
\hline Palangwe West & CFR & 1963 & 184 & $\begin{array}{l}\text { Woodland that burns ever year. Not valuable for water catchment. Fuel } \\
\text { wood gathering. }\end{array}$ \\
\hline Ruvu & CFR & 1955 & 3094 & $\begin{array}{l}\text { Woodland and lowland forest. A lot of mining damage and some logging. } \\
\text { Fuel and pole gathering. }\end{array}$ \\
\hline Shikurufumi & CFR & 1948 & 260 & Plantation and secondary forest. Fuel and pole gathering. \\
\hline Uluguru North & CFR & $\begin{array}{l}\text { German colonial } \\
\text { and } 1961\end{array}$ & 8357 & $\begin{array}{l}\text { Large area of submontane to upper montane forest. Farmland encroachment } \\
\text { and illegal hunting, pit sawing and fuel and pole gathering. }\end{array}$ \\
\hline Uluguru South & CFR & German colonial & 17293 & $\begin{array}{l}\text { Large area of montane to upper montane forest with some grasslands. } \\
\text { Farmland encroachment and illegal hunting, pit sawing and fuel and } \\
\text { pole gathering. }\end{array}$ \\
\hline Vigoza & CFR & Cap. 1321950 & 9 & Former plantation, now cleared and farmed. Fuel and pole gathering. \\
\hline Mangala & DFR & $? 1968$ & 35 & $\begin{array}{l}\text { Local authority reserve largely managed by the village with lowland forest } \\
\text { under threat from conversion to farmland. Fuel and pole gathering. }\end{array}$ \\
\hline Milawilila & DFR & ?1968 & & $\begin{array}{l}\text { Local authority reserve largely managed by the village with lowland forest } \\
\text { under threat from conversion to farmland. Fuel and pole gathering. }\end{array}$ \\
\hline Ngambaula & DFR & ?1968 & & $\begin{array}{l}\text { Local authority reserve largely managed by the village with lowland forest } \\
\text { under threat from conversion to farmland. Fuel and pole gathering. }\end{array}$ \\
\hline Nguru Ya Ndege & DFR & 1962 & 38190 & $\begin{array}{l}\text { Outlying hill west of Ulugurus. Mainly woodland with a little forest on the } \\
\text { top. Lots of damage from timber, charcoal, fuelwood and pole cutting. }\end{array}$ \\
\hline Konga & Village & 1910 & 5 & $\begin{array}{l}\text { De-gazetted and now managed by the village. Good lowland forest, with } \\
\text { some tree cutting for local use. }\end{array}$ \\
\hline
\end{tabular}

${ }^{*}$ CFR, Catchment Forest Reserve managed by the central government Forest and Beekeeping Division Catchment Forestry Project; DFR, Local Authority Forest Reserve managed by the local government Morogoro Rural District; Village, a former Forest Reserve that has been de-gazetted, but which still contains forest.

stuhlmanni tropicalis, the snakes Typhlops uluguruensis, Typhlops sp. nov. (D. Broadley, pers. com.), and Prosymna ornatissima, and the amphibian Hyperolius tornieri.

Of the 135 plant taxa endemic to the Uluguru Mountains (Table 3) two are species in monotypic genera: Rhipidiantha chlorantha and Dionychastrum schliebenii. The need for additional botanical exploration is illustrated by the fact that 31 of the endemic taxa are too imperfectly known to be adequately described, the habitat of five taxa is not recorded, and the altitudinal range of one species is not known. The currently available data indicates that the endemic plant species generally have restricted altitudinal ranges, occupying a mean of 2.2 $200 \mathrm{~m}$ altitudinal bands. Sixty taxa are known from only 
Table 2 Vertebrate taxa endemic to the Uluguru Mountains, with author and date of description, occurrence in closed mature forest only or in closed forest and forest edge, and occurrence in the four altitudinal zones of montane habitat.

\begin{tabular}{|c|c|c|c|c|c|c|}
\hline \multirow[b]{2}{*}{ Species } & \multirow[b]{2}{*}{ Described } & \multirow[b]{2}{*}{$\begin{array}{l}\text { Forest } \\
\text { habitat* }\end{array}$} & \multicolumn{4}{|c|}{ Altitudinal zone } \\
\hline & & & $\begin{array}{l}\text { Lowland } \\
(0-800 \mathrm{~m})\end{array}$ & $\begin{array}{l}\text { Submontane } \\
(800-1400 \mathrm{~m})\end{array}$ & $\begin{array}{l}\text { Montane } \\
(1400-1800)\end{array}$ & $\begin{array}{l}\text { Upper Montane } \\
(>1800)\end{array}$ \\
\hline \multicolumn{7}{|l|}{ Birds } \\
\hline Malaconotus alius & Friedmann, 1927 & FF & & $\mathrm{x}$ & $x$ & \\
\hline Nectarinia loveridgei & Hartert, 1922 & FF & & $\mathrm{x}$ & $\mathrm{x}$ & $\mathrm{x}$ \\
\hline \multicolumn{7}{|l|}{ Mammals } \\
\hline Crocidura telfordi & Hutterer, 1986 & $\mathrm{FF}$ & & & $\mathrm{x}$ & \\
\hline Myosorex geata & Allen \& Loveridge, 1927 & FF & & & $\mathrm{x}$ & $\mathrm{x}$ \\
\hline${ }^{1}$ Chrysochloris stuhlmanni tropicalis & Allen \& Loveridge, 1927 & F & & & $x$ & $x$ \\
\hline \multicolumn{7}{|l|}{ Reptiles } \\
\hline Lygodactylus williamsi & Loveridge, 1952 & FF & $\mathrm{x}$ & & & \\
\hline${ }^{1}$ Prosymna ornatissima & Barbour \& Loveridge, 1928 & $\mathrm{~F}$ & & $\mathrm{x}$ & & \\
\hline Rhampholeon uluguruensis & Tilbury \& Emmrich, 1996 & FF & & $\mathrm{x}$ & $\mathrm{x}$ & \\
\hline${ }^{1}$ Typhlops uluguruensis & Barbour \& Loveridge, 1928 & $\mathrm{~F}$ & & $x$ & & \\
\hline${ }^{1}$ Typhlops sp. nov. & Broadley in lit. & $\mathrm{F}$ & & $x$ & & \\
\hline \multicolumn{7}{|l|}{ Amphibians } \\
\hline${ }^{1}$ Hyperolius tornieri & Ahl, 1931 & $\mathrm{FF}$ & & & $\mathrm{x}$ & \\
\hline Nectophrynoides cryptus & Perret, 1971 & FF & & & $\mathrm{x}$ & $\mathrm{x}$ \\
\hline Nectophrynoides minutus & Perret, 1972 & FF & & & $\mathrm{x}$ & $\mathrm{x}$ \\
\hline Nectophrynoides sp.nov. & Howell in lit. & FF & & & $\mathrm{x}$ & \\
\hline Probreviceps uluguruensis & Loveridge, 1925 & FF & & & $x$ & $x$ \\
\hline Scolecomorphus uluguruensis & Barbour \& Loveridge, 1928 & FF & & & $x$ & \\
\hline Totals & & & 1 & 6 & 12 & 6 \\
\hline
\end{tabular}

*FF, closed mature forest only; $\mathrm{F}$, closed mature forest and forest edge.

${ }^{1}$ Taxa that have not been recorded in the last 10 years.

one $200 \mathrm{~m}$ band, 25 from 2 bands, 26 from 3 bands, 11 from 4 bands, 8 from 5 bands, 3 from 6 bands and 1 from 7 bands. Most endemic taxa occur in forest (121), 20 occur in other habitats, and 11 occur both in forest and in other habitats. Limiting the list to species endemic only to the Uluguru Mountains may under-record the botanical importance of non-forest habitats; for example, the Lukwangule Plateau grasslands contain some nearendemics such as Moraea callista and Panicum lukwangulense that also occur in a restricted number of localities in high mountains further south.

Of the plant families not checked, both Acanthaceae and Gesneriaceae contain Uluguru endemics. In the Acanthaceae Isoglossa ixodes, I. oreacanthoides and Sclerochiton ulugurensis are endemic species and Epiclastopelma is an endemic genus with two species: E. glandulosum and E. macranthum. In the Gesneriaceae Saintpaulia goetzeana and several Streptocarpus species are endemic, and Linnaeopsis is an endemic genus with three species: L. alba, L. heckmanniana and L. subscandens. Many species are near-endemics. For example, the recently described Zenkerella perplexa, thought to be endemic to Bondwa in the northern Uluguru Mountains (Temu, 1990), has also been located on Malundwe Hill south of the Mountains
(Lovett, 1993b). Some genera are near-endemics, for example the monotypic Urogenitas ulugurensis is known only from the Uluguru, Ukaguru and Nguru Mountains, and the monotypic Neobenthamia gracilis is known only from the Uluguru and Nguru Mountains.

\section{Discussion}

One of our aims was to investigate whether the biodiversity of the Uluguru Mountains has changed over the last 50 years. Results of forest status and biodiversity surveys indicate that, despite the extensive loss of forest in lowland and submontane areas (Figs. 2 \& 3), many of the endemic animal taxa still survive. However, four of the Uluguru endemic animal species, three of them, snakes, have not been located (Table 2). Although snakes can be difficult to locate, the fact that their preferred habitat of low to middle altitudes (700-1,000 m) has been intensively deforested is a cause for concern. Two bird species previously recorded $(P$. nicolli and A. rubritorques) have not been located for decades and, although they occur elsewhere, they might be extinct in the Uluguru Mountains. 
Table 3 Preliminary list of plant taxa endemic to the Uluguru Mountains (see text for details of compilation), with an indication of those taxa that are as yet imperfectly known, occurrence in forest or other habitat, and occurrence in altitudinal bands of $200 \mathrm{~m}$ from $<400$ to $>2,400 \mathrm{~m}$. A taxon is endemic at the lowest taxonomic level indicated, with the exception of the monotypic genera Rhipidiantha and Dionychastrum.

\begin{tabular}{|c|c|c|c|c|c|c|c|c|c|c|c|c|c|c|c|}
\hline \multirow[b]{2}{*}{ Taxon } & \multirow{2}{*}{$\begin{array}{l}\text { Imperfectly } \\
\text { known }\end{array}$} & \multirow[b]{2}{*}{ Forest } & \multirow{2}{*}{$\begin{array}{l}\text { Other } \\
\text { habitat }\end{array}$} & \multicolumn{12}{|c|}{ Altitudinal bands (m) } \\
\hline & & & & $<400$ & 400 & 600 & 800 & 1000 & 1200 & 1400 & 1600 & 1800 & 2000 & 2200 & $>2400$ \\
\hline Acridocarpus congestus & & $x$ & & & & & & & $\mathrm{x}$ & $\mathrm{x}$ & $\mathrm{x}$ & & & & \\
\hline Arisaema ulugurense & & $x$ & $x$ & & & & & & & & & & $x$ & $x$ & \\
\hline $\begin{array}{l}\text { Balthasaria schliebenii var. } \\
\text { schliebenii }\end{array}$ & & $x$ & & & & & & & & $\mathrm{x}$ & $\mathrm{x}$ & $\mathrm{x}$ & & & \\
\hline Baphia pauloi & & $x$ & & $x$ & & & & & & & & & & & \\
\hline Blotiella coriacea & & & $x$ & & & & & & & & $x$ & & & & \\
\hline Bulbophyllum concatenatum & & $x$ & & & & & & & & $\mathrm{x}$ & $\mathrm{x}$ & $\mathrm{x}$ & & & \\
\hline Callipteris ulugurica & & $x$ & & & & & $x$ & $x$ & & & & & & & \\
\hline Canthium sp. B & $x$ & $x$ & & & & & & & & $x$ & $x$ & & & & \\
\hline $\begin{array}{l}\text { Chassalia discolor subsp. } \\
\text { grandifolia }\end{array}$ & & $\mathrm{x}$ & & $\mathrm{x}$ & & & & & & & & & & & \\
\hline Chassalia sp. A & $\mathrm{x}$ & $x$ & & & & & & & & & & & & $\mathrm{x}$ & \\
\hline $\begin{array}{l}\text { Chassalia violacea var. } \\
\text { parviflora }\end{array}$ & & $x$ & & & & & & $\mathrm{x}$ & $\mathrm{x}$ & $\mathrm{x}$ & $\mathrm{x}$ & $\mathrm{x}$ & & & \\
\hline $\begin{array}{l}\text { Chassalia violacea var. } \\
\text { violacea }\end{array}$ & & $x$ & & & & & & & $x$ & $x$ & $x$ & $x$ & & & \\
\hline Clerodendrum suffruticosum & & $x$ & $x$ & & & & & & $\mathrm{x}$ & $x$ & $\mathrm{x}$ & & & & \\
\hline Coccinia ulugurensis & & $x$ & $x$ & & & & & & $x$ & & & & & & \\
\hline Coffea sp. A & $x$ & $x$ & & $x$ & & & & & & & & & & & \\
\hline Coffea sp. E & $x$ & $x$ & & & $x$ & & & & & & & & & & \\
\hline Commiphora ulugurensis & & $x$ & & $x$ & & & & & & & & & & & \\
\hline Cremaspora sp. A & $\mathrm{x}$ & $x$ & & & & & & & & & & $\mathrm{x}$ & & & \\
\hline Crotalaria hemsleyi & & & $x$ & & & & & & $\mathrm{x}$ & $\mathrm{x}$ & & & & & \\
\hline $\begin{array}{l}\text { Cryptotaenia calycina var. } \\
\quad \text { dissecta }\end{array}$ & & $x$ & & & & & & & & & & & & $\mathrm{x}$ & \\
\hline Cynometra ulugurensis & & $x$ & & & & $x$ & & & & & & & & & \\
\hline Cyphostemma gracillimum & & & $\mathrm{x}$ & & & $x$ & $\mathrm{x}$ & $x$ & & & & & & & \\
\hline $\begin{array}{l}\text { Cyphostemma masukuense } \\
\text { subsp. ulugurense }\end{array}$ & & $\mathrm{x}$ & $\mathrm{x}$ & & & & & & & & & & $\mathrm{x}$ & $\mathrm{x}$ & \\
\hline Cyphostemma sp. P & $x$ & $x$ & & $x$ & & & & & & & & & & & \\
\hline Diaphananthe orientalis & & $x$ & & & & & & & & & & $\mathrm{x}$ & & & \\
\hline Dionychastrum schliebenii & & & $x$ & & & & & & & & & & & $x$ & $x$ \\
\hline Diospyros corylicarpa & & $x$ & & & $x$ & & & & & & & & & & \\
\hline Diplazium ulugurense & & $x$ & & & & & & & & & $x$ & & & & \\
\hline Dorstenia dionga & & $x$ & & & & & & & $\mathrm{x}$ & $x$ & $x$ & & & & \\
\hline Dorstenia ulugurensis & & $x$ & & & & & & & & & $x$ & $x$ & & & \\
\hline $\begin{array}{l}\text { Drypetes usambarica var. } \\
\text { stylosa }\end{array}$ & & $x$ & & $\mathrm{x}$ & & & & & & & & & & & \\
\hline Ehretia rosea & $\mathrm{x}$ & & & $\mathrm{x}$ & & & & & & & & & & & \\
\hline Epipactis ulugurica & & $x$ & $x$ & & & & & & & & & & $x$ & $x$ & $x$ \\
\hline Garcinia bifasciculata & & $x$ & & $x$ & & & & & & & & & & & \\
\hline Genus unknown & $\mathrm{x}$ & $x$ & & $x$ & & & & & & & & & & & \\
\hline Gravesia hylophila & & $x$ & $x$ & & & & & $x$ & $\mathrm{x}$ & $x$ & & & & & \\
\hline $\begin{array}{l}\text { Gravesia pulchra var. } \\
\quad \text { pulchra }\end{array}$ & & $x$ & & & & & & & $\mathrm{x}$ & $\mathrm{x}$ & $\mathrm{x}$ & & & & \\
\hline Gravesia riparia & & $x$ & & & & & & & & $x$ & & & & & \\
\hline Grumilea blepharostipula & $x$ & $x$ & & & & & & & & & $x$ & & & & \\
\hline Grumilea chaunothyrsus & $x$ & $x$ & & & & & & & & $x$ & & & & & \\
\hline Grumilea euchrysantha & $x$ & $x$ & & & & & & $x$ & & & & & & & \\
\hline Grumilea pallidiflora & $\mathrm{x}$ & & & $x$ & & & & & & & & & & & \\
\hline Ilex mitis var. schliebenii & & $x$ & & & & & & & & & & & & & $x$ \\
\hline Impatiens barbulata & & $x$ & & & & & & & & & $x$ & $x$ & & & \\
\hline Impatiens cinnabarina & & $x$ & & $x$ & $\mathrm{x}$ & & & & & & & & & & \\
\hline Impatiens humifusa & & $x$ & & & & & $x$ & $x$ & $\mathrm{x}$ & & & & & & \\
\hline Impatiens ioides & & $x$ & & & & & & & $x$ & $x$ & $x$ & $x$ & & & \\
\hline Impatiens lukwangulensis & & $x$ & & & & & & & & & $x$ & $x$ & $x$ & $x$ & $x$ \\
\hline
\end{tabular}


Table 3 (continued)

\begin{tabular}{|c|c|c|c|c|c|c|c|c|c|c|c|c|c|c|c|}
\hline \multirow[b]{2}{*}{ Taxon } & \multirow{2}{*}{$\begin{array}{l}\text { Imperfectly } \\
\text { known }\end{array}$} & \multirow[b]{2}{*}{ Forest } & \multirow{2}{*}{$\begin{array}{l}\text { Other } \\
\text { habitat }\end{array}$} & \multicolumn{12}{|c|}{ Altitudinal bands (m) } \\
\hline & & & & $<400$ & 400 & 600 & 800 & 1000 & 1200 & 1400 & 1600 & 1800 & 2000 & 2200 & $>2400$ \\
\hline $\begin{array}{l}\text { Impatiens pallide-rosea subsp. } \\
\text { pallide-rosea }\end{array}$ & & $x$ & & & & & & & & & & & $x$ & $x$ & $x$ \\
\hline Impatiens pseudohamata & & $x$ & & & & & & & & & & & & $\mathrm{x}$ & \\
\hline Impatiens serpens & & $\mathrm{x}$ & & & & & & & & $x$ & $x$ & $x$ & $x$ & $x$ & \\
\hline Impatiens simbiniensis & & $x$ & & & & & & & & $x$ & & & & & \\
\hline Impatiens thamnoidea & & $x$ & & & & & & & & & & $\mathrm{x}$ & $\mathrm{x}$ & & \\
\hline Impatiens tricaudata & & $x$ & & & & & & & & & & & & & $x$ \\
\hline Impatiens ulugurensis & & $x$ & & & & & & & & & $\mathrm{x}$ & $\mathrm{x}$ & $x$ & $x$ & $x$ \\
\hline Jasminum rotundatum & $\mathrm{x}$ & $x$ & $x$ & & & & & $\mathrm{x}$ & & & & & & & \\
\hline Keetia sp. C & $x$ & $x$ & & & & & & & & $x$ & $x$ & & & & \\
\hline Lasianthus cereiflorus & & $x$ & & & & & & $x$ & $x$ & $x$ & $x$ & & & & \\
\hline $\begin{array}{l}\text { Lasianthus glomeruliflorus } \\
\text { var.? }\end{array}$ & $\mathrm{x}$ & $x$ & & & & & & & $x$ & $\mathrm{x}$ & $\mathrm{x}$ & & & & \\
\hline $\begin{array}{l}\text { Lasianthus glomeruliflorus } \\
\text { var. glomeruliflorus }\end{array}$ & & $x$ & & & & & & & & & $x$ & & & & \\
\hline Lasianthus grandifolius & & $x$ & & & & & & & & & & & $x$ & & \\
\hline Lasianthus macrocalyx & & $\mathrm{x}$ & & & & & & & & & & $\mathrm{x}$ & $\mathrm{x}$ & $\mathrm{x}$ & $x$ \\
\hline Lasianthus microcalyx & & $x$ & & & & & & & & & & & $x$ & $x$ & $x$ \\
\hline Lasianthus sp. A & $x$ & $x$ & & & & & & & & $x$ & & & & & \\
\hline Lasianthus wallacei & & $x$ & & & & & & & & & $x$ & $x$ & & & \\
\hline Lasianthus xanthospermus & & $\mathrm{x}$ & & & & & & & & & & & & & $x$ \\
\hline Lingelsheimia sylvestris & & $x$ & & $x$ & & & & & & & & & & & \\
\hline Lobelia gilgii & & & $x$ & & & & & & & $x$ & $x$ & $\mathrm{x}$ & $x$ & $x$ & $x$ \\
\hline Lobelia graniticola & & & $x$ & & & & & & & & & & $x$ & $x$ & $x$ \\
\hline Lobelia lukwangulensis & & $x$ & $x$ & & & & & & & & & $x$ & $x$ & $x$ & $x$ \\
\hline Lobelia morogoroensis & & $x$ & & & & & $x$ & $x$ & $\mathrm{x}$ & $x$ & $x$ & $x$ & & & \\
\hline Margelliantha globularis & & $x$ & & & & & & & $x$ & & & & & & \\
\hline Meineckia acuminata & & $x$ & & & & & & & $x$ & $x$ & $x$ & & & & \\
\hline Memecylon myrtilloides & & $x$ & & & & & & & $\mathrm{x}$ & $x$ & $x$ & $x$ & & & \\
\hline Mimusops penduliflora & & $x$ & & & & $x$ & & & & & & & & & \\
\hline $\begin{array}{l}\text { Necepsia castaneifolia subsp. } \\
\quad \text { kimbozensis }\end{array}$ & & $\mathrm{x}$ & & $x$ & & & & & & & & & & & \\
\hline Oncella gracilis & & $x$ & & & & & & & & & $x$ & & & & \\
\hline $\begin{array}{l}\text { Ophrypetalum odoratum } \\
\text { subsp. longipedicellatum }\end{array}$ & & $\mathrm{x}$ & $x$ & $x$ & $\mathrm{x}$ & & & & & & & & & & \\
\hline $\begin{array}{l}\text { Pauridiantha symplocoides } \\
\text { var.? }\end{array}$ & $x$ & $x$ & & & & & & & $\mathrm{x}$ & & & & & & \\
\hline Pavetta bruceana & & $x$ & & & & & & & & & & & $x$ & $x$ & \\
\hline $\begin{array}{l}\text { Pavetta constipulata var. } \\
\text { constipulata }\end{array}$ & & $\mathrm{x}$ & & & & & & & $\mathrm{x}$ & $x$ & $\mathrm{x}$ & & & & \\
\hline $\begin{array}{l}\text { Pavetta constipulata var. } \\
\text { uranoscopa }\end{array}$ & & $x$ & & & & & $x$ & $x$ & & & & & & & \\
\hline $\begin{array}{l}\text { Pavetta crebrifolia var. } \\
\text { kimbozensis }\end{array}$ & & $x$ & & & $\mathrm{x}$ & & & & & & & & & & \\
\hline Pavetta filistipulata & & $x$ & & & & & & $x$ & $x$ & $x$ & & & & & \\
\hline Pavetta sparsipila & & $x$ & & & & & & & $x$ & $x$ & & & & & \\
\hline Peddiea puberula & & $\mathrm{x}$ & & & & & & & $x$ & $x$ & $x$ & $x$ & $x$ & & \\
\hline Pentas ionolaena & & $\mathrm{x}$ & $x$ & & & & & & $x$ & $x$ & $x$ & $x$ & $\mathrm{x}$ & & \\
\hline Pentas pseudomagnifica & & $x$ & $x$ & & & & & & & & & & $x$ & $x$ & $x$ \\
\hline Pentas ulugurica & & $x$ & & & & & & $x$ & $x$ & $x$ & $x$ & & & & \\
\hline Phyllanthus thulinii & & & $x$ & & & & & & & $x$ & $x$ & $x$ & & & \\
\hline Pilea goetzei & & $x$ & & & & & & & $\mathrm{x}$ & $x$ & $x$ & $x$ & $x$ & & \\
\hline Pittosporum goetzei & & $x$ & & & & & & & & & & & $x$ & $x$ & \\
\hline Polystachya longiscapa & & & $x$ & & & & & $x$ & $x$ & $x$ & & & & & \\
\hline Polystachya lukwangulensis & & $x$ & & & & & & & & & & & & $x$ & \\
\hline Polystachya porphyrochila & & $x$ & & & & & & & & $x$ & & & & & \\
\hline $\begin{array}{l}\text { Pseudonesohedyotis } \\
\text { bremekampii }\end{array}$ & & $x$ & & & & & & & $x$ & $x$ & $x$ & $x$ & $\mathrm{x}$ & $x$ & $x$ \\
\hline
\end{tabular}


Table 3 (continued)

\begin{tabular}{|c|c|c|c|c|c|c|c|c|c|c|c|c|c|c|c|}
\hline \multirow[b]{2}{*}{ Taxon } & \multirow{2}{*}{$\begin{array}{l}\text { Imperfectly } \\
\text { known }\end{array}$} & \multirow[b]{2}{*}{ Forest } & \multirow{2}{*}{$\begin{array}{l}\text { Other } \\
\text { habitat }\end{array}$} & \multicolumn{12}{|c|}{ Altitudinal bands (m) } \\
\hline & & & & $<400$ & 400 & 600 & 800 & 1000 & 1200 & 1400 & 1600 & 1800 & 2000 & 2200 & $>2400$ \\
\hline Pseudosabicea arborea & & $x$ & & & & & & & & & $x$ & $x$ & $x$ & & \\
\hline Psychotria brucei & & $x$ & & & & & & & & & $x$ & $x$ & $x$ & $\mathrm{x}$ & \\
\hline Psychotria castaneifolia & & $x$ & & & & & & & $x$ & & & & & & \\
\hline Psychotria cephalidantha & $x$ & & & & & & & & & & & & & & \\
\hline Psychotria diploneura & & $x$ & & & & & & & & & & & $x$ & & \\
\hline Psychotria elachistantha & & $x$ & & & & & & & $x$ & $x$ & $x$ & $x$ & & & \\
\hline Psychotria megistantha & & $x$ & & & & & & & & $x$ & $x$ & $x$ & $x$ & $x$ & $x$ \\
\hline Psychotria sp. D & $x$ & $x$ & & & & & & & & & & & & $\mathrm{x}$ & $x$ \\
\hline Psychotria sp. I & $\mathrm{x}$ & $x$ & & & & & & & & $x$ & & & & & \\
\hline Psychotria sp. N & $x$ & $x$ & & & & & & & & $x$ & & & & & \\
\hline $\begin{array}{l}\text { Psychotria tanganyicensis } \\
\text { subsp. longipes }\end{array}$ & & $\mathrm{x}$ & & & & & & & & & & $\mathrm{x}$ & & & \\
\hline Rhipidantha chlorantha & & $x$ & & & & & & & & $x$ & $x$ & & & & \\
\hline Rinorea sp. A & $x$ & $x$ & & $x$ & & & & & & & & & & & \\
\hline $\begin{array}{l}\text { Rytigynia lichenoxenos } \\
\text { subsp. lichenoxenos }\end{array}$ & & $x$ & & & & & & & & & & $\mathrm{x}$ & $\mathrm{x}$ & $\mathrm{x}$ & \\
\hline Rytigynia nodulosa & & $x$ & & & & & & & $x$ & $x$ & $x$ & $x$ & $x$ & & \\
\hline Rytigynia sp. F & $x$ & $x$ & & & & & & & & $x$ & $x$ & & & & \\
\hline Stapfiella ulugurica & & $x$ & & & & & & & & & & $x$ & $x$ & & \\
\hline Stolzia angustifolia & & $x$ & & & & & & & & & & $x$ & & & \\
\hline Stolzia atrorubra & & $x$ & & & & & & & & & & $x$ & $x$ & $\mathrm{x}$ & \\
\hline Stolzia moniliformis & & $x$ & & & & & & & $x$ & $x$ & $x$ & $x$ & & & \\
\hline Stolzia oligantha & & $x$ & & & & & & & & & $\mathrm{x}$ & $x$ & & & \\
\hline Stolzia viridis & & $x$ & & & & & & & & & $x$ & $x$ & & & \\
\hline Synsepalum ulugurense & $x$ & $x$ & & & & & & & & $x$ & $x$ & & & & \\
\hline $\begin{array}{l}\text { Syzygium micklethwaitii } \\
\text { subsp. subcordatum var. } \\
\text { subcordatum }\end{array}$ & & $\mathrm{x}$ & & & & & & & & & & & $\mathrm{x}$ & $\mathrm{x}$ & $\mathrm{x}$ \\
\hline Syzygium parvulum & & $x$ & & & & & & & & & & $x$ & $x$ & $x$ & \\
\hline Syzygium sp. A & $\mathrm{x}$ & $x$ & & & & & & & $x$ & & & & & & \\
\hline Tarenna quadrangularis & & $x$ & & & & & & & $x$ & $x$ & $x$ & & & & \\
\hline Ternstroemia polypetala var.? & $x$ & $x$ & & & & & & & & & & $\mathrm{x}$ & $x$ & $\mathrm{x}$ & \\
\hline Thylachium alboviolaceum & $\mathrm{x}$ & & & $\mathrm{x}$ & & & & & & & & & & & \\
\hline Thylachium densiflorum & & & & & & & $x$ & & & & & & & & \\
\hline Thylachium macrophyllum & $\mathrm{x}$ & & $\mathrm{x}$ & & $\mathrm{x}$ & & & & & & & & & & \\
\hline Tridactyle sarcodantha & & $x$ & & & & & & & & & & $x$ & & & \\
\hline Turrea kimbozensis & & $x$ & & $x$ & $x$ & & & & & & & & & & \\
\hline $\begin{array}{l}\text { Turrea mombassana subsp. } \\
\text { schliebenii }\end{array}$ & & $\mathrm{x}$ & & & & & & & & $\mathrm{x}$ & & & & & \\
\hline Vepris mildbraediana & $x$ & $x$ & & & & & & & & & & $x$ & & & \\
\hline $\begin{array}{l}\text { Vepris morogorensis var. } \\
\text { subalata }\end{array}$ & & $\mathrm{x}$ & & $\mathrm{x}$ & & & & & & & & & & & \\
\hline Vepris sp. A & $x$ & $x$ & & & & & & & & & $x$ & & & & \\
\hline Vernonia tricholoba & & $x$ & & & & & & & & & & & & $x$ & \\
\hline Vitex sp. A & $x$ & $x$ & & $x$ & & & & & & & & & & & \\
\hline Totals & 31 & 121 & 20 & 19 & 7 & 3 & 6 & 13 & 33 & 46 & 48 & 42 & 32 & 30 & 18 \\
\hline
\end{tabular}

The fact that so many of the plant and animal species endemic to the Uluguru Mountains have a restricted forest distribution illustrates the threat posed by the extensive loss of forest. The Endangered Uluguru Bush Shrike Malaconotus alius provides an example of how the process of habitat loss and species decline may be linked. Ecological surveys of this species (Romdal et al., unpub.) have shown that it prefers lower altitude forests with good canopy cover, but this is the forest that has been most affected by deforestation. There are many records of this species in the Uluguru North Forest Reserve and in the non-reserved forests that used to occur outside this Reserve, and a single record of the species from $2,100 \mathrm{~m}$ in the Uluguru South Forest Reserve above Tchenzema (Collar \& Stuart, 1985; Stuart \& Jensen, 1985). Surveys of Uluguru South in early 2000 failed to locate the species, although it is extant in Uluguru North (Burgess et al., 2001). The clearance of the lower altitude 
forest at the southern end of the Uluguru Mountains to $>1,500 \mathrm{~m}$ on the eastern face and c. $2,000 \mathrm{~m}$ on the western face might have resulted in this species becoming extirpated from this Reserve, leaving it confined to one reserve that has a total area of $<100 \mathrm{~km}^{2}$. The continuing deforestation of the lower altitude forests in Uluguru North (Figs. $2 \& 3$ ) is a cause for concern for the future of this species.

Studies of the altitudinal distribution of endemic plants in eastern Tanzanian forested mountains illustrates that endemic forest plants occur throughout the elevational range of the forests, and that many of these species are confined to a narrow range of altitude (Lovett et al., 2001). The loss of forest over a particular range will therefore inevitably lead to species loss. As some of the lower altitudes on the Uluguru Mountains have lost almost all their forest cover over the last 40-50 years, plant species may have disappeared or become extinct. Further surveys of the endemic plant species of the Uluguru Mountains are required to determine how many can still be located and whether any have become extinct.

Although we have focused on the endemic vertebrates and plants of the Uluguru Mountains, there is also a rich invertebrate fauna with hundreds, and probably thousands, of endemic species (see references in Burgess et al., 1998b). Similar to the plants, many species of endemic invertebrate can be expected to inhabit a narrow altitudinal range in the forest. With deforestation at particular altitudes, invertebrate species might have become extinct, or at least reduced in distribution to remnant forest patches along streams and on rocky outcrops.

The fact that almost all the forest on the Uluguru Mountains is now found within the boundaries of the Catchment Forest Reserves managed by the Tanzanian Government is a strong vindication of the value of these reserves for the conservation of biodiversity. This was not their original aim, as most of the forests were reserved for their water catchment functions and to prevent landslides and flooding downstream (Lovett \& Pócs, 1993; Rodgers, 1993). However, the protection function of the Forest Department, backed up by legislation and by a government structure down to village level, has been remarkably successful for biodiversity conservation. Local people respect Reserve boundaries, even in remote areas where government forest officers rarely visit (pers. obs.). The importance of maintaining the reserves is further emphasized by comparison with the Shume-Magamba Reserve in the West Usambara Mountains of Tanzania, where 12,000 ha were excised from the Reserve in 1963, resulting in the almost total conversion of the forest to farmland (Lovett \& Stuart, 2001; Lovett, unpub.).
In 1955 the Uluguru North and Uluguru South forests were connected across the Bunduki Depression (Fig. 2), and hence there could have been exchange of species between the two Reserves. This connection has been severed through conversion to farmland, and a dense human population now occupies the area. Most of the forest species of Uluguru South and North will now be confined to the Reserves, making them more vulnerable to extinction, because many of the forest specialist species will not venture across large gaps (Fjeldså, 1999).

In addition to their importance as a centre of endemic biodiversity, the Uluguru Mountains are also the most important water catchment in Tanzania. This is because the Ruvu River rises in these mountains, and then forms the principal water supply to the residents of Dar es Salaam, the largest city in Tanzania. However, despite this importance, the value of the forests as a catchment area for millions of people in Tanzania is poorly documented. Previous studies by Pócs (1974, 1976a, b) described how the forests assist in trapping water that then flows to Morogoro and Dar es Salaam, but there is only preliminary data on the water flow from the mountains (Jackson, 1970; Temple, 1972a, b), and there is no information of how water flows might have changed over time. Critically, it is not known whether deforestation of the Uluguru Mountains has caused any change in water flow from the mountains. Anecdotal evidence from local village elders in the region of Kitumbaku/Kitundu Hills, and from our own observations, indicates that, as the forests have been cleared, the cloud base has moved to ever higher altitudes.

To secure the future of the forests and biodiversity of the Uluguru Mountains the importance of the area needs to be better appreciated, both in Tanzania and further afield. The most readily appreciated reason to conserve these forests is their role in supplying water to the largest city in the country. Additional links need to be made between these immediate water values, the importance of the area for biodiversity conservation, and the modest funding needs of the managers of the Catchment Forest Reserves where the vast majority of the forest is now found.

\section{Acknowledgements}

We gratefully acknowledge the following people who have gathered the data used in this paper: Jakob Kiure, Boniface Mhoro, R.P.C. Temu, V.R. Nsolomo, Elias Mungaya, John Mejissa, Lamek Noah, Cheyo Mayuma, Odette Karamaga, Andrew Perkin, Alan Channing, Tom Romdal, Marcel Rahner, Klaus Sørensen, Louis Hansen, the late Jens Otto Svendsen, Line Sørensen, Jon Fjeldså, Nikolaj Scharff, Flemming Pagh-Jensen, Simon Stuart, Tamas Pócs, William Stanley, Kim Howell, Alan Rodgers, 
Julian Bayliss, Charles Msuya and Olivier Hymas. We also gratefully acknowledge the assistance of Dr Henk Beentje and Dr Kaj Vollesen at the Royal Botanic Gardens, Kew for assistance in compiling the list of endemic plants.

\section{References}

Allen, G.M. \& Loveridge, A. (1927) Mammals from the Uluguru and Usambara Mountains, Tanganyika Territory. Proceedings of the Boston Society of Natural History, 38, 413-441.

Barbour, T. \& Loveridge, A. (1928) A comparative study of the herpetological fauna of the Uluguru and Usambara Mountains, Tanganyika Territory with descriptions of new species. Memoirs of the Museum of Comparative Zoology, Harvard, 50, 87-265.

Bensted-Smith, R. \& Msangi, T.H. (1989) Report on the Conservation of Ecosystems and Genetic Resources. Tanzania Forestry Action Plan, Dar es Salaam, United Republic of Tanzania.

Burgess, N.D. \& Clarke, G.P. (eds) (2000) The Coastal Forests of Eastern Africa. IUCN Forest Conservation Programme, Gland, Switzerland and Cambridge, UK.

Burgess, N.D., Clarke, G.P. \& Rodgers, W.A. (1998a) Coastal forests of eastern Africa: status, endemism patterns and their potential cause. Biological Journal of the Linnean Society, 64, 337-367.

Burgess, N.D., Fjeldså, J. \& Botterweg, R. (1998b) Faunal importance of the Eastern Arc Mountains of Kenya and Tanzania. Journal of the East African Natural History Society, 87, 37-58.

Burgess, N.D., Nummelin, M., Fjeldså, J., Howell, K.M., Lukumbyzya, K., Mhando, L., Phillipson, P. \& Vanden Berghe, E. (eds) (1998c) Biodiversity and Conservation of the Eastern Arc Mountains of Tanzania and Kenya. Journal of the East African Natural History Society, 87, 1-367.

Burgess, N.D., Romdal, T.S. \& Rahner, M. (2001) Forest loss in the Ulugurus, Tanzania and the status of the Uluguru Bush Shrike Malconotus alius. Bulletin of the African Bird Club, 8, 89-90.

Channing, A. (2000) Summary of the Amphibians of the Uluguru Mountains. Unpublished Report, Wildlife Conservation Society of Tanzania, Morogoro. Available at http:/ / www.africanconservation.com/uluguru

Collar, N.J. \& Stuart, S.N. (1985) Threatened Birds of Africa and Related Islands: The ICBP/IUCN Red Data Book. International Council for Bird Preservation and IUCN, Cambridge, UK

Doggart, N., Lovett, J., Mhoro, B., Kiure, J. \& Burgess, N.D. (2001) Biodiversity Surveys in Eleven Forest Reserves in the Vicinity of the Uluguru Mountains, Eastern Tanzania. Wildlife Conservation Society of Tanzania, Morogoro. Available at http:/ / www.africanconservation.com/uluguru

ESRI (2000) ArcInfo, version 7.0. ESRI Corporation, Redlands, USA

Fjeldså, J. (1999) The impact of human forest disturbance on the endemic avifauna of the Udzungwa Mountains, Tanzania. Bird Conservation International, 9, 47-62

Government of Tanzania (1998) New Forest Policy. Forest and Beekeeping Division, Dar es Salaam, Tanzania.

Government of Tanzania (2001) Tanzania Forest Programme. Forest and Beekeeping Division, Dar es Salaam, Tanzania.
Hymas, O. (1999) Bananas in the hills. MSc thesis, University College, London. Available at http:/ / www. africanconservation.com/uluguru

Hymas, O. (2000) Assessment of the Remaining Forests on the Uluguru Mountains and the Pressures they Face. Technical Report, Uluguru Mountains Biodiversity Conservation Project. Available at http:/ /www.africanconservation.com/ uluguru

ICBP (1992) Putting Biodiversity on the Map: Priority Areas for Global Conservation. International Council for Bird Preservation, Cambridge, UK.

Jackson, I.J. (1970) Rainfall over the Ruvu Basin and Surrounding Area. Report No. 9, Bureau of Resource Assessment and Land Use Planning Research, Dar es Salaam, Tanzania.

LEAP (List of East African Plants) (1995) Annotated List of East African Plants. National Museums of Kenya, Nairobi, Kenya.

Loveridge, A. (1942) Scientific results of a fourth expedition to forested areas in East and Central Africa. IV. Reptiles. Bulletin of the Museum of Comparative Zoology, Harvard, 91, 237-373.

Lovett, J.C. (1988) Endemism and affinities of the Tanzanian montane forest flora. In Proceedings of the Eleventh Plenary Meeting of the Association for the Taxonomic Study of Tropical Africa (eds P. Goldblatt \& P.P. Lowry). Monographs in Systematic Botany from the Missouri Botanical Garden, 25, 591-598.

Lovett, J.C. (1990) Classification and status of the moist forests of Tanzania. Mitteilungen aus dem Institut für Allgemeine Botanik Hamburg, 23a, 287-300.

Lovett, J.C. (1993a) Eastern Arc moist forest flora. In Biogeography and Ecology of the Rain Forests of Eastern Africa (eds J.C. Lovett \& S.K. Wasser), pp. 33-55. Cambridge University Press, Cambridge, UK.

Lovett, J.C. (1993b) A new locality for Zenkerella perplexa in Tanzania. East Africa Natural History Society Bulletin, 23, 53-54.

Lovett, J.C. (1998) Importance of the Eastern Arc mountains for vascular plants. Journal of the East African Natural History Society, 87, 59-74.

Lovett, J.C., Clarke, G.P., Moore, R. \& Morrey, G. (2001) Elevational distribution of restricted range forest tree taxa in eastern Tanzania. Biodiversity and Conservation, 10, 541-550.

Lovett, J.C. \& Pócs, T. (1993) Assessment of the Condition of the Catchment Forest Reserves, A Botanical Appraisal. Catchment Forestry Report 93.3, Forest and Beekeeping Division, Ministry of Tourism, Natural Resources and Environment, Dar es Salaam, Tanzania.

Lovett, J.C. \& Stuart, S.N. (2001) Avifauna and vegetation of the Shume Juniperus forest in the West Usambara mountains, Tanzania. Scopus, 21, 1-14.

Lovett, J.C. \& Wasser, S.K. (eds) (1993) Biogeography and Ecology of the Rain Forests of Eastern Africa. Cambridge University Press, Cambridge, UK.

Mittermeier, R.A., Myers, N., Thompsen, J.B., da Fonesca, G.A.B. \& Olivieri, S. (1998) Global biodiversity hotspots and major tropical wilderness areas. Conservation Biology, 12, 516-520.

Mittermeier, R.A., Myers, N., Gil, P.R. \& Mittermeier, C.G. (1999) Hotspots: Earth's Biologically Richest and most Endangered Terrestrial Ecoregions. CEMEX, Mexico City, Mexico.

Moreau, R.E. (1966) The Bird Faunas of Africa and its Islands. Academic Press, London, UK. 
Myers, N., Mittermeier, R.A., Mittermeier, C.G., da Fonseca, G.A.B. \& Kent, J. (2000) Biodiversity hotspots for conservation priorities. Nature, 403, 853-858.

Olson, D. \& Dinerstein, E. (1998) The Global 200: a representation approach to conserving the Earth's most biologically valuable ecoregions. Conservation Biology, 12, 502-515.

Perkin, A. (2000) Status of the mountain galago Galagoides orinus in the Ulugurus. Unpublished Report, Wildlife Conservation Society of Tanzania, Morogoro. Available at http://www.africanconservation.com/uluguru

Pócs, T. (1974) Bioclimatic studies in the Uluguru Mountains (Tanzania, East Africa) I. Acta Botanica Academiae Scientarium Hungaricae, 20, 115-135.

Pócs, T. (1976a) Bioclimatic studies in the Uluguru Mountains (Tanzania, East Africa) II. Correlations between orography, climate and vegetation. Acta Botanica Academiae Scientarium Hungaricae, 22, 163-183.

Pócs, T. (1976b) Vegetation mapping in the Uluguru Mountains (Tanzania, East Africa). Boissera, 24, 477-498.

Pócs, T. (1998) Bryophyte diversity along the Eastern Arc. Journal of the East African Natural History Society, 87, 75-84.

Polhill, R.M. (1968) Tanzania. In Conservation of Vegetation in Africa South of the Sahara (eds I. Hedberg \& O. Hedberg). Acta Phytogeographica Suecica, 54, 166-78.

Rodgers, W.A., Hall, J.B. \& Mwasumbi, L. (1983) Kimboza Forest Reserve. Report to the Ministry of Natural Resources and Tourism, Dar es Salaam, Tanzania.

Rodgers, W.A. (1993) The Conservation of the forest resources of eastern Africa: past influences, present practices and future needs. In Biogeography and Ecology of the Rain Forests of Eastern Africa (eds J.C. Lovett \& S. Wasser), pp. 283-331. Cambridge University Press, Cambridge, UK.

Stanley, W.T., Kihaule, P.M., Howell, K.M. \& Hutterer, R. (1998) Small mammals of the Eastern Arc Mountains, Tanzania. Journal of the East African Natural History Society, 87, 91-100.

Stattersfield, A.J., Crosby, M.J., Long, A.J. \& Wege, D.C. (1998) Endemic Bird Areas of the World: Priorities for Biodiversity Conservation. BirdLife International, Cambridge, UK.

Stuart, S.N. \& Jensen, F.P. (1985) The avifauna of the Uluguru Mountains, Tanzania. Gerfaut, 75, 155-187.
Svendsen, J.O. \& Hansen, L.A. (eds) (1995) Report on the Uluguru Biodiversity Survey 1993. Parts A and B. Unpublished Report, Tanzania Forestry Research Institute, Royal Society for the Protection of Birds, and Danish Centre for Tropical Biodiversity.

Temple, P. (1972a) Soil and water conservation policies in the Uluguru Mountains Tanzania. Geografiska Aannaler, 54A, 110-123.

Temple, P. (1972b) Measurements of runoff and soil erosion at erosion plot scale with particular reference to Tanzania. Geografiska Aannaler, 54A, 203-221.

Temu, R.P.C. (1990) A new species of Zenkerella (Leguminosae: Caesalpinioideae) from Tanzania. Nordic Journal of Botany, 10, 421-423.

Temu, R.P.C. \& Nsolomo, V.R. (2000) List of the Uluguru Mountain Endemic and Near-Endemic Vascular Plants. Unpublished Report, Wildlife Conservation Society of Tanzania, Morogoro. Available at http:/ /www. africanconservation.com/uluguru

\section{Biographical sketches}

Neil Burgess has studied the biology of Tanzanian forests since 1989 and has been involved with conservation projects on the Uluguru Mountains since the early 1990s. Most recently he was a Technical Advisor on the Uluguru Mountains Biodiversity Conservation Project between 1999 and 2001.

Nike Doggart has worked in Tanzania for over 5 years. She has coordinated forest surveys in the East Usambara, Udzungwa and Uluguru Mountains, and now works as the Projects Coordinator for the Tanzania Forest Conservation Group, which runs conservation projects at a number of forest sites.

Jon Lovett undertook botanical fieldwork in the forests of Tanzania for more than 10 years, and first coined the phase 'Eastern Arc' to describe the range of mountains containing the Ulugurus. He has maintained close links with Tanzanian botanists and conservationists since returning to the UK to take up a position at the University of York. 